\title{
The Evaluation of the Subtrochanteric Osteotomy
}

By

\section{K.Okano and U. Kitaoka}

Department of Orthopedic Surgery, Medical Faculty, Tottori University

(Director : Prof.Dr.D.Kashiwagi)

It is said that subtrochanteric osteotomy is the treatinent of choice for irreducible congenital and pathological dislocation of the hip joint, though it is a conservative treatment.

We examined 11 cases (11 hips) which had elapsed one year or more after operation, in making this report the length of follow-up has been too short. The results are not so good as we expected, particularly the flexion of several hips was restricted remarkarbly.

This bad mobility of the operated hips is due to the excessive anterior angulation at the site of osteotomy which is caused during the fixation in cast of paris and not due to the operative failure.

Therefore, by the use of internal fixation and postoperative lateral roentgenograms the fragments can be efficiently maintained in the desired proper position and the good mobility of the hip can be secured.

\section{Acryl樹脂によるJudet人工骨頭の自家製作法}

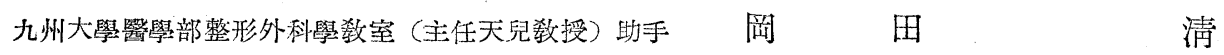

\section{I 緒豪}

現今歯科用Resinの名称で呼ばれている Metacryl 樹脂の起源はかなり古く，1901年既にドイッで Otto Röhm飞より基礎的な研究がなされたが此の樹脂が工栄的に生産されたのは比較的に新しい。 歯科領域に用いられたのは, 日, 英, 米, 独何れも時を同じくし大体1936年〜1937年頃と言われる。 其の後幾多の研究者の絶えざる研究努力により化学的物理的機淢的諸性質の改善検討を経て今日の 発達を見たのである。整形外科領域への合成樹脂（Resin）の応用はやはり1937年年以降であつて Smith-Petersen, Mellon, Phalen氏等の文献にBakelite, Lucite, Plexiglass, Diakon等の名称で散見 される。欠損された骨の代用として又関節成形術に応用されているが重要視されるに至らなかつね 然るに1949年仏のJudet兄弟が Polymethyl-Metacrylate にて大腿骨々頭を作製し，股関節成形術に 応用し優秀なる結果を得たと報告した。此の合成樹脂人工骨頭は多くの人々イより追試賞用され， 
今日Vitalliumと共に関節成形術に於ける非吸収性中間摴入物質として重要視されるに至つた。

然らば此のPolymethyl-Metacrylate とは如何なるものかしばらく合成樹脂とついての説明を試み よう。

\section{Acryl系樹脂及びその性質}

合成樹脂とは天然高分子化合物に対して，合成され た高分子化合物に与えられた名称である。最初合成さ れたものが天然の樹脂に似ていたから此れを合成した 樹脂と称したのであるが，樹脂の分子量は 304 である から科学的に此の名称は妥当ではない，全くの固有名 詞である。

1) 合成樹脂の分類 合成樹脂はその原料又はその 性質からも分類出来るが，花沢，永井氏に従い熱硕化 性樹脂と熱可塑性樹脂に分類するのが簡単である, 前 者は加熱により硬化して再びもとに㴆らない性質のも のであり，後者は加熱により溶融してもとに滞る性質 である゚(表Iの如し)

表 I 合成樹脂の分類(花沢，永井氏による)

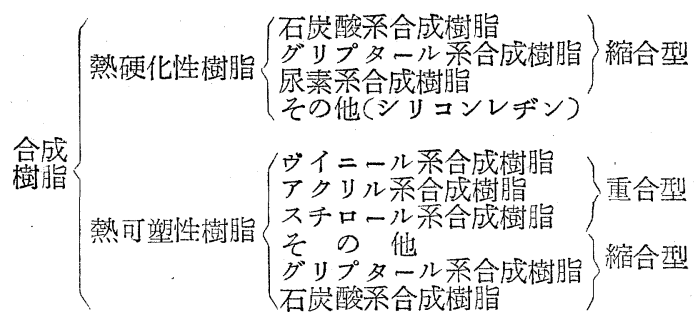

今日齒科用Resin として広く用いられているものは Acryl 系合成樹脂であるから Acrylicresin 又は単に Resin (樹脂) と呼ばれる。

Acrylicresinはエチレン誘導体であつてAcryl酸の 化学構造はH $\mathrm{H}$ であり<smiles></smiles>

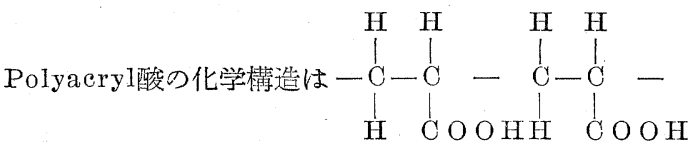
である。而して

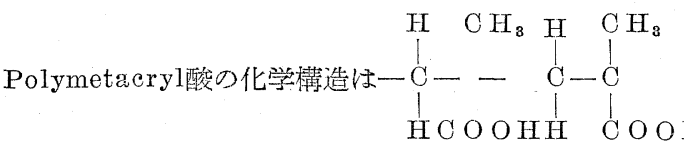
である。

Resin の硬度は化学構成上より，女る程度側鎖間の分 子引カが重大な影響をむつのであるからPolyacryl 酸
よりPolymetacryl 酸の方が硬度が高い。又カルボキ シル基COOHによる吸水性を除くため，この酸のエス テル化が考它ら，現在吾人はこの酸のメチルエステ ルを使用しているのである。即ち<smiles>CCC(C)C(=O)OCl</smiles><smiles>CCCC(C)(C)C(C)C</smiles>
Polymethylmetacrylateであつて最も優秀なるのである。

市販に供される場合にはResin の液 (単量体) とこ れに触媒（主に過酸化ベンゾイル）を加えて乳化重合 法によつて得られるResinの粉末（重合体）とから出 来ていて，使朋に便利になつている。吾国には「バイ オレデン」「アクリコン」「フデコン」「ネオレヂン」等 の製品がある。

2）Acrylicresinの性質 各製品共其の製造過程に 於て多少の相違があり, 従つてその物珜化学的性質並 びに機械的性質に関しても自ら差違の生ずるは自然で ある。然し此等の諸性質に関しては宮津, 永井; 金竹. 今関氏等の研究娭討により日進月歩の状況に岗つて外 国製品に比し，いささか妇㝽色はないのである。Acrylicresin は強勒性, 可塑性, 䨘気絶縁性, 透光性に 富み, 爇更び電気伝導率は極めて低く，その強度攻び 硬度は表IIの如く鉄の約 $1 / 4$ 亿相当し骨の代用として充 分である。

㝨（II）（宫潅氏による）

\begin{tabular}{|c|c|c|c|c|}
\hline \multirow{2}{*}{$\begin{array}{l}\text { 抗張力 } \\
\mathrm{kg} / \mathrm{cm}^{2}\end{array}$} & \multirow{2}{*}{$\begin{array}{l}\text { 彎曲力 } \\
\mathrm{kg} / \mathrm{cm}^{2}\end{array}$} & \multirow{2}{*}{$\begin{array}{l}\text { 衝㨻力 } \\
\mathrm{kg} / \mathrm{cm}^{2}\end{array}$} & \multicolumn{2}{|c|}{ 硬度 } \\
\hline & & & ショア- & ブリネル \\
\hline 480 & 980 & 12.9 & 7.1 & 12.7 \\
\hline
\end{tabular}

上記の如く優れた機械的性質を有し，耐酸，耐了ル カリで吸水量も少く耐水性であるが熱に対して弱い欠 点がある。即引耐熱温度 $125^{\circ} \mathrm{C}$, 連続响熱温度 $49 \sim 71^{\circ} \mathrm{C}$, 彎曲温度 $63^{\circ} \sim 88^{\circ} \mathrm{C}$ で岉る。且有機溶媒に溶け易いので 細菌学的滅菌操作が困難である。更に欠点として挙げ られる点はレ線に対する透過性で焉る。猶磨耗性は帚 頭として用いる場合蹦牀的に重要性つない事を動物実 験から知つた。

\section{3) Acrylicresinの生牧學的檢討}


美濃口，横溝氏等により研究されて生体組織に対してて は何等障害を与完ず，且Resin は生体内に永く移入さ れて何等の変化を当受けない事が期らかにされてい る。

此等の研究を基礎として人体組織内に Resin移入に よる各種臨牀的㐫用面が拓かれた。即ち肋膜外合成樹 脂球充填術; 隆悬術, 顔面耳整形術, 義眼更び恩地氏 のResin-Cup等がある。私は天等教授指導のもとに菌 科口腔外科教空の方々の御援助御指導を得てJudet合 、成樹脂人工骨頭の実験的並びに臨林的研究の機会を与. えられ，人工骨頭の製作を経験した。私はこ〉に私の 経験し得た製作法を紹介し諸賢の御追訊を願うもので める。

\section{III 製 作 方 法}

必垌とする材料及び器具はその都度説明する。

1) 陰性模型の製作 先づ骨頭及び軸の狯型を作ら なくてはならない，骨頭は後藤風雲堂の厚意により Vitallium-Cup作製用の陰型を借りたが, 大腿骨々頭 を用いて石麗で作り得る。嵮は適当な大きさの鉄柱を 用いて陰型を作つた。此の陰型に加熱溶解したParaffin-Waxを流し，込む。冷却するを待つて取り出せば陽 性のParaffin-Wax骨頭攻び淢が得られる。两者を接 合し彫刻刀を用いて調整し陽性 Paraffin-Wax骨頭を 作る, 此の祭アンダーカット蔡び軸の形状索䧓刻して 特く。

蒸和用フラスコの下盈に石亮を充填し，此の骨頭の 半分を埋没する。石高が乾澡したならば分離棛(松風会 社製セーパレイション又は濃厚クレブール液)を叙布 する。乾燥後フラスコ上盆を被いて石高にて埋没,蓋を する。此の際石諪が模型のアンダーカットの部分迄充 分行き互る如く注意をする。石亮が固まり充分強固に なるのを待つてフラスコを爇湯中に大れParaffinを溶 解する。上下盈を開きParaffin充全にに除去し, 出 来上つた陰性模型が冷却しないらちにアルギン酸 $\mathrm{Na}$ を塗布する。此れは重合中 Resin を水から守るためと 石膏との分離をよくするためである。陰性石高模型が 完全に冷却してから次の垻入操作に移る。

2) 䬺狀物Dough or Plastic の製成 予如測定し て扔いた Paraffin-Wax 模型重量と同重量の Resin粉 末 (重合体)を取り，シャーレに入れ，これの1 $/ 2$ 量の Resin 液 (単量体) を除々に湿和する。容器の中で混 和物は次の 3 段階を経て餅状物となる, 此の時期は非 常に可塑性に富み「フラスコ」にResin を填入する時
期である。

即ち 1. しめり砂Dampsand

2. 杼状 Mushy

3. ベとべとSticky

4. 餅状 Dough or Plastic

此の変化は単量体が重合体飞侵大乙て行く拡散であ つて，重合物の部分的溶解であると考它られている。 即ち化学的変化ではなく物理的变化である。此の䬺状 の状態に到達する迄の時間は外界温度と粉未の重合度 更び粉未と液との量の関係によつて左右されるもので 所要時間に対しては何等の法則もない，従つて経験に よる外はない。

3）償入 混和物が领状物となつた時期に先に用意 した陰型模型の「フラスコ」に填入する。此の際 18$8 \mathrm{SMO}$ 鋼の軸及び梁を埋没する，前者は補強のために 後者はレ線写真の示標のためである。

次に試圧のため「セロフアン」紙を被ふ。試圧は除々 に且断続的に行つて可塑性に富む餅状物が総ての陰型 の微細部に大り込むやらにする。

上下盈を開いて過剩部分を除去する。

再び圧を加へる，此の時は急激な匠を加える，充分 Resinを圧縮して招かないと重合中に起る Resinの収 縮のため変形を生ずる恐れがある。

4）溫成 此れは䬼状物を「フラスコ」に填入して から「フラスコ」疍冷却して完成された骨頭を取り出 す汔を意味し, 重合反応はこの期間中の一部分であ る。温成操作の目的は液体の単量体を個体の重合体に 変ずることで此の操作が Resin骨頭の強度に重大なる 意義を持つのである。

温成期間中気泡が発生しないやう, 更に強度を充分 発揮せしめるため, 種々の研究検討が行われているが $65^{\circ} \sim 70^{\circ} \mathrm{C} 1$ 時間, $100^{\circ} \mathrm{C} 1$ 時間，合計 2 時間の著沸が よいと言われている。私の経験では除々に温度を上梨 せしめ $70^{\circ} \mathrm{C}$ とな，これで 1 時間ついで $100^{\circ} \mathrm{C} 1$ 時間， 合計約 3 時間を要して充分なる時間を与えた方が立派 な作品を得るとこが出来た。「フラスコ」が自然冷却を してから Rosin骨頭を取り出さないと歪を生ずる危険 がある。

出来上つたResin 骨頭にしばしば大小種々の気泡が 見られる，表䤄に現れない内部の小さな球状気泡は 温成中の念激な温度上景のため単量体が気泡として残 留するものである。表面, 内部と Resin骨頭を貫く如 く見える不規則で比較的大きな気泡は餅状となる前に 
填入した場合である。

表面，内部に不規則で球状でない前 2 者の中間位の 気泡は匟の不足のため生じたものである。此等の気泡 は製作者の注意で防止出来るが表面に班点状の小さな 針孔として現はれる気泡は使用した粉未中に已に気泡
がある場合生ずるものである。

5）䁌 斯くして出来上つたResin骨頭の下縁に 烽 0.3 㱫の小孔 8 個老「バー」で穿ち，「サンドメ゚ーパ 一」及び「フェルト」を以て充分研磨すれは透明滑沢 な完成品を得る。(写真参照)

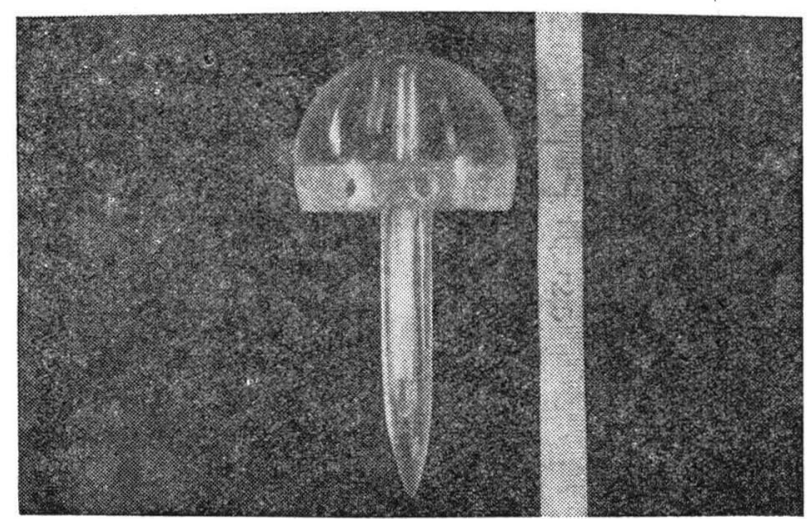

骨頭, 直芼 $4 \mathrm{~cm}$, 内烽 $3 \sim 3.5 \mathrm{~cm}$ 高さ約 $3 \mathrm{~cm}$ の半球状

軸. 長さ $6 \sim 7 \mathrm{~cm}$ 直俻 1 。细の柱比 又は 4 条の溝のある円柱。状

結 語

以上私は自ら経験し得た Polymethyl-Metacrylate:こよるJudet合成樹指人工骨頭の製作法を紹介 した。諸賢の御追陚を乞ら次第である。

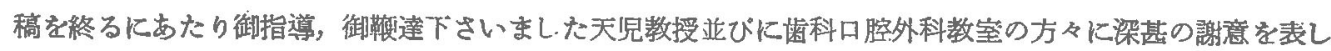
ます。

\section{考交喤}

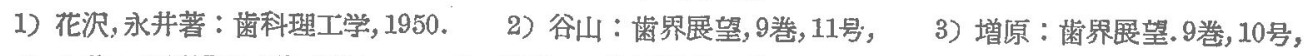
4) 永井: 歯界展望, 9 巻. 10 号.
5) 美漉口: 画界展望, 9 巻, 10 号.
6) 金竹: 䕰科学報, 51 巻, 6 号.

7) 水島: 蒛科学報, 50 巻, 3 量.

8) 美濃口: 臨牀菌科No.1867号, 1949.

9) 今関：臨牀菌科, No。

190,11 昼, 1950 .

10) 佐竹: 臨牀菌科No. 194, 15号, 1951. 


\title{
How I could made Judet's artificial femoral head
}

from acrylic resin?

By

Kiyoshi Okada

Department of Orthopedic Surgery, Kyushu University

(Director : Dr. T.Amako)

\begin{abstract}
Acrylic resin, which is harmiess to the living body and unchangeable in the on account of its superior physical, chemical, and mechanical characteristics, is now widely applied in the various fields of clinics. But this resin has the disadvantages being fusible at rather low er degree of the heat and difficult to be sterilised.

I made the Judet's artificial femoral head of acrylic resin in accordance with the general method by which a tooth-plate is made, using as its material polymethyl-metacrylate made in our country. The point to which I had to pay the most caref ul attention in the making of this artificial femoral head was how to cure the material and get best article having no foam in it. For this purpose, I at first boiled the material untill the heat of $70^{\circ} \mathrm{C}$ spending about an hour, and then kept it being boiled at the same heat for an hour and at the heat of $100^{\circ} \mathrm{C}$ for the same hour respectively; spending three hours in all.

The femoral head of my own device has 8 holes of $0.3 \mathrm{~cm}$ diametre at its rin, by which its fixation can be strengthened.
\end{abstract}

\section{觔關節並に遷延治㾤骨折の原因に関する統計的觀察}

九州大學醫學部整形外科學敉室 (主任 天兒敋授) 後藤 建… 郎

緒 霉

骨折治療面に現れた多くの統計に依ると，偽関節並に骨折の遷延治癒が相当数に及んでいる。此 の偽関節並飞骨折の遷延治瘾の発生の頻度は, 戦時と平時とに於てかなりの差異がみられるが, 平 時に於ては大凡全骨折の $0.4 \sim 0.5 \%$ (Bruns), 戦時に於ては3.5〜 6\%の高率にみられ，今次大戦に 於けるアメリカでの統計では $2.75 \%$ 高率を示している。

此の様な偽関節並飞骨折の遷延治瘾の成因が如何をる妈にあるかを明にするため, 昭和11年島教

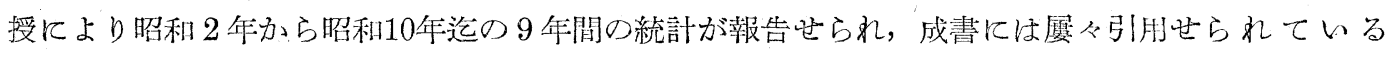
が，私は昭和12年 1 月から昭和 27 年 4 月に至る15年 4 万月閒に於て，我が教空外来を訪れた偽関節 患者 242 例, 遷延治瘾骨折患者21例, 合計 263 の症例の原因に関して調查し, 骨折治療法の変遷之 